\title{
Virittäjän nykytila ja tulevaisuus lukijoiden puntarissa
}

Virittäjän lukijatutkimus toteutettiin lokamarraskuussa 2017. Edelliskerran lukijoiden mielipiteitä selvitettiin vuonna 2011 (ks. Niskanen \& Mäntynen 2012). Uudelle tutkimukselle oli tarvetta, sillä tiedekustantamisen muutokset ja haasteet jatkuvat ja esimerkiksi paineet välittömään avoimeen julkaisemiseen kasvavat. Moni lehti on luopunut painetusta julkaisusta ja siirtynyt pelkästään verkkoon. Näissä myllerryksissä Virittäjäkin joutuu arvioimaan, miten turvata lehden toimintaedellytykset ja miten kehittää toimintaa jatkossa niin, että julkaisu palvelisi parhaalla mahdollisella tavalla lukijoitaan. Vaikka Kotikielen Seuran ja sen aikakauslehden Virittäjän takana on paljon talkootyötä, laadukkaan lehden toimittaminen on mahdotonta ilman riittäviä taloudellisia resursseja. Tämän kyselyn toteuttamisen mahdollisti Suomen tiedekustantajien liiton myöntämä apuraha, mistä lausumme lämpimän kiitoksen. ${ }^{1}$

Sähköisesti toteutettuun kyselyyn tuli kaikkiaan 306 vastausta, mikä on hivenen vähemmän kuin edellisellä kerralla, jolloin vastaajia oli 344 (Niskanen \& Mäntynen 2012: 125). Kyselyyn olisi ollut mahdollista vastata myös paperisella lomakkeella, mutta kaikki vastaajat täyttivät kyselyn sähköisesti. Lukijatutkimuksesta tiedotettiin Virittäjässä (sekä painetussa lehdessä 3/2017 että Verkko-Virittäjässä), sähköpostilistoilla, Facebookissa ja OJSjärjestelmän kautta niille, jotka ovat rekisteröityneet OJS:n käyttäjiksi. Kaikkien vas-

1. Kyselyn toteutti filosofian maisteri Jenni Neuvonen. taajien kesken arvottiin kolme Virittäjän vuosikertaa.

Tässä raportissa keskitymme tuloksiin, jotka koskevat verkko- ja paperilehden käyttöä, tilausmaksuja, julkaisun avoimuutta sekä lehden sisältöä. Aivan aluksi kerromme taustatietoa vastaajista.

\section{Kyselyn vastaajat}

Vastaajilta tiedusteltiin ikää, sukupuolta, ammattia tai päätoimea, koulutusalaa, tilaaja-, lukija- ja kirjoittajatietoja sekä osallistumista Virittäjän toimitukseen. Opettajilta kysyttiin lisäksi opetusalaa. Suurin yksittäinen vastaajaryhmä oli opettajat, joita oli noin kolmasosa $(31 \%){ }^{2}$ Kun mukaan lasketaan tutkija-opettajat (17\%), opetustehtävissä toimivien osuus vastaajista on lähes puolet. Tutkija-opettajista miltei kaikki työskentelevät yliopistossa, kun taas muista opettajista siellä toimii vain kourallinen. Toiseksi ahkerimmin kyselyyn vastasivat perustutkinto-opiskelijat (23 \%). Jatko-opiskelijoita vastaajista oli kymmenesosa ja tutkijoita miltei saman verran (9\%). Lisäksi tutkimukseen osallistui esimerkiksi viestinnän ammattilaisia.

Yli 80 prosenttia vastaajista oli naisia. Vastaajia oli muuten melko tasaisesti eri ikäryhmistä, mutta yli 6o-vuotiaita oli muita vähemmän. Liki 40 prosenttia ilmoitti työ- tai opiskelupaikakseen Helsingin. Toiseksi eniten vastaajia (n. $15 \%$ ) oli Jyväskylästä; muut jakautuivat melko ta-

2. Opettajien huomattavaan osuuteen vaikutti todennäköisesti se, että kyselyä levitettiin myös Äidinkielen opettajain liiton sähköpostilistan kautta. 
saisesti suomen kielen opetusta tarjoavien yliopistokaupunkien kesken. Lisäksi useita vastauksia tuli muualta Suomesta ja ulkomaisista suomen opetuspisteistä. Vastaajista miltei 80 prosenttia ilmoitti koulutusalakseen suomen kielen, mutta joukossa oli myös esimerkiksi suomen sukukielten, yleisen kielitieteen ja muiden kielten edustajia.

Vastaushetkellä Virittäjää kertoi tilaavansa hieman alle puolet vastaajista (44\%); vuoden 2011 kyselyssä tilaajien osuus vastaajista oli noin 9 prosenttiyksikköä pienempi (Niskanen \& Mäntynen 2012: 126). Kun tilaajien osuutta tarkastellaan vastaajaryhmittäin, huomataan, että se on suurin tutkija-opettajien (67\%) ja jatkoopiskelijoiden $(53 \%)$ ryhmissä; perustutkinto-opiskelijoista (37\%), opettajista (35\%) ja tutkijoista (32\%) nykyisiä tilaajia oli vain noin kolmannes. Lukumääräisesti eniten tilaajissa oli tutkija-opettajia ja opettajia. Aiemmin Virittäjää kertoi tilanneensa vajaat 15 prosenttia kaikista vastanneista, kun taas noin 40 prosenttia ei ollut koskaan ollut lehden tilaajia. Jopa 38 prosenttia niistä vastaajista, jotka eivät olleet Virittäjän tilaajia, kertoi lukevansa lehteä kirjastossa ja noin viidesosa työpaikallaan.
Kyselyssä tiedusteltiin myös sitä, miten ahkerasti vastaajat Virittäjää lukevat. Runsas kolmannes (35\%) ilmoitti lukevansa lehteä säännöllisesti, ja silloin tällöin lehteen tarttuu hieman yli puolet (56\%). Sen sijaan noin kymmenesosa (9 \%) tunnusti, ettei lue Virittäjää, mutta innostui silti osallistumaan kyselyyn. Tästä joukosta valtaosa oli opettajia. Lukutottumukset olivat varsin samanlaisia myös edellisen kyselyn vastaajilla (vrt. Niskanen \& Mäntynen 2012: 126). Kuviossa 1 lukemisen säännöllisyyttä on eritelty vastaajaryhmittäin. Ahkerimpia lukijoita näyttäisivät olevan kyselyn valossa tutkija-opettajat, kun taas opettajavastaajissa oli eniten niitä, jotka eivät lue lehteä lainkaan.

Kun kyselyssä tiedusteltiin, mikä saa vastaajat lukemaan Virittäjää, eniten suosiota keräsi vaihtoehto, jonka mukaan motiivina on pysyä selvillä uusimmasta tutkimuksesta. Sen oli valinnut noin 86 prosenttia lehteä lukevista vastaajista. Vastausten perusteella Virittäjää hyödynnetään paljon myös lähdemateriaalina; yli puolet vastanneista lukijoista ilmoitti käyttävänsä lehteä oman opinnäytetyön tai muun tutkimuksen lähteenä tai etsivänsä sen avulla sopivaa kirjallisuutta. Noin 30 prosenttia

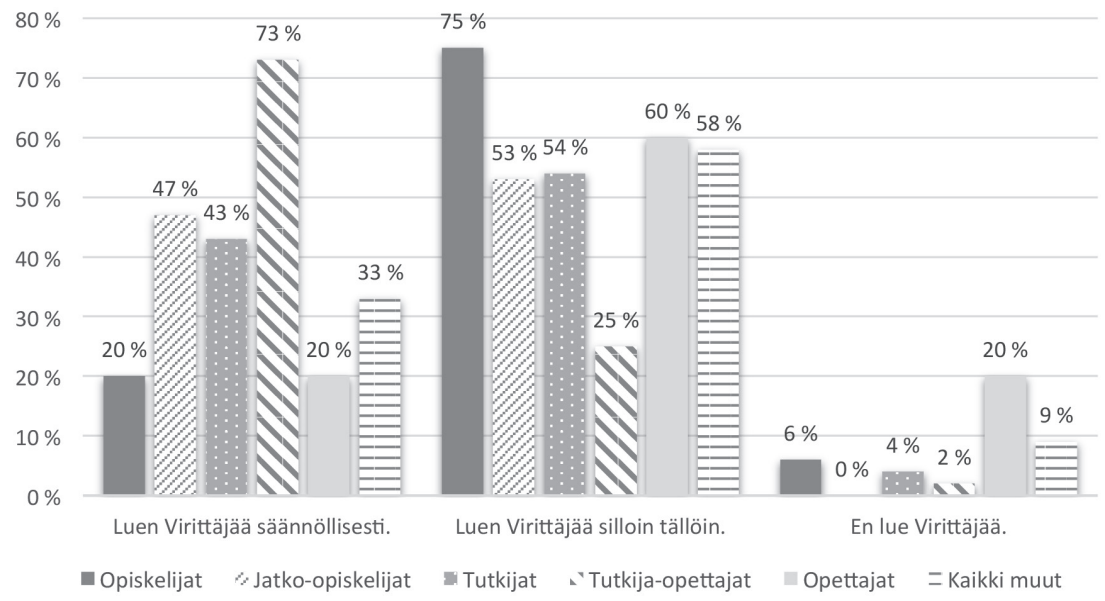

Kuvio 1.

Virittäjän lukeminen vastaajaryhmittäin. 
kertoi hyödyntävänsä Virittäjää opetusmateriaalina. Vastauksista ilmenee, että moni käyttää Virittäjää useampaan kuin yhteen tarkoitukseen, sillä joka kymmenes oli valinnut kaikki edellä esitellyt vaihtoehdot. Lisäksi mainittiin esimerkiksi silkka mielenkiinto kielitieteeseen ja suomenkieliseen tieteelliseen julkaisemiseen, kuten seuraavista kommenteista ilmenee:

"Ajattelen tukevani suomenkielistä alan tieteellistä kirjoittamista."

"Sisältö on kiinnostavaa!"

Vapaamuotoisissa kommenteissa tuli myös esiin, että Virittäjä on monelle potentiaalinen omien tekstien julkaisukanava, mikä osaltaan motivoi lukemaan sitä. Lehteen oli kirjoittanut runsas neljännes vastaajista. Virittäjän toimittamiseen puolestaan kertoi vuosien varrella osallistuneensa noin kuudesosa.

Suurin osa Virittäjää lukevista vastaajista ilmoitti seuraavansa myös muita tieteellisiä julkaisuja. He luettelivat ahkerasti eri lehtiä - niin suomenkielisiä kuin kansainvälisiäkin. Moni mainitsi lukevansa kokonaan vain Virittäjän tai tilaavansa ainoastaan sitä mutta seuraavansa sen ohella myös monia muita julkaisuja.

\section{Virittäjän verkkosivut}

Lomakkeen toisen osion kysymykset liittyivät Virittäjän verkkosivujen käyttöön ja kehittämiseen. Kolme neljäsosaa kyselyyn vastanneista kertoi käyttäneensä lehden verkkosivuja. Suosituin verkkopalvelu on arkisto, jota on hyödyntänyt 85 prosenttia verkkosivujen käyttäjistä. Lähes yhtä suuri osa tästä joukosta ilmoitti käyttäneensä sivuja kirjoitusten lukemiseen (79 \%) ja tiedonhakuun ( $78 \%)$. Reilu kolmasosa on hyödyntänyt verkkosivuilta kirjoittajan oh-

3. Lainaukset ovat alkuperäisessä kirjoitusasussaan. jeita, minkä lisäksi sivuilla käydään tulostamassa kirjoituksia luettavaksi, lähettämässä omia tekstejä arvioitavaksi tai hakemassa apua oman opetuksen valmisteluun. Valtaosa hyödyntää verkkosivuja moneen eri tarkoitukseen.

Virittäjän verkkosivuihin ollaan pääosin tyytyväisiä. Eniten toivotaan hakutoimintojen parantamista ja monipuolistamista. Osa vapaamuotoisista vastauksista kuitenkin paljastaa, etteivät kaikki vastaajat ole tietoisia siitä, mitä verkkosivuilta voi hakea (esim. aiheen mukainen haku). Vastauksissa toivotaan myös lisää vanhempaa materiaalia verkkoon. Tähän toiveeseen ollaan parastaikaa vastaamassa, sillä Suomen tiedekustantajien liitto on tukenut Virittäjän vanhojen artikkelien digitointia, ja viime aikoina on siirretty verkkoon runsaasti 1980- ja 1990-luvun kirjoituksia - niiltä osin kuin kirjoituksiin on saatu tekijöiltä tai oikeudenomistajilta julkaisulupa. Vastauksissa esitetään myös ideoita verkkosivujen ulkoasun kehittämiseen.

\section{Painettu ja verkkoversio}

Yksi kyselyn keskeisistä tavoitteista oli tiedustella vastaajien mielipiteitä painetun ja verkkolehden käytöstä sekä tilaushinnoista. Yli puolet vastaajista (55 \%) ilmoitti lukevansa Virittäjää sekä paperisena että sähköisesti. Suhteellisesti eniten molempien versioiden käyttäjiä on tutkijaopettajissa ja jatko-opiskelijoissa (ks. kuviota 2). Vajaa neljännes (23\%) kertoi lukevansa ainoastaan paperilehteä ja 16 prosenttia vain verkkolehteä; loput (6 \%) eivät ottaneet kantaa. Pelkästään painettua lehteä lukevista suurimman ryhmän muodostavat opettajat. Tilaajien osuus paperilehden lukijoista oli 58 prosenttia. Pelkkää sähköistä versiota käyttävistä enemmistö kertoi lukevansa Virittäjää verkosta jälkikäteen, kun sisällöt ovat tulleet avoimiksi. Heistä runsas kolmannes oli opiskelijoita.

Vastaajilta, jotka lukevat Virittäjää sekä paperisena että sähköisesti, tiedusteltiin 


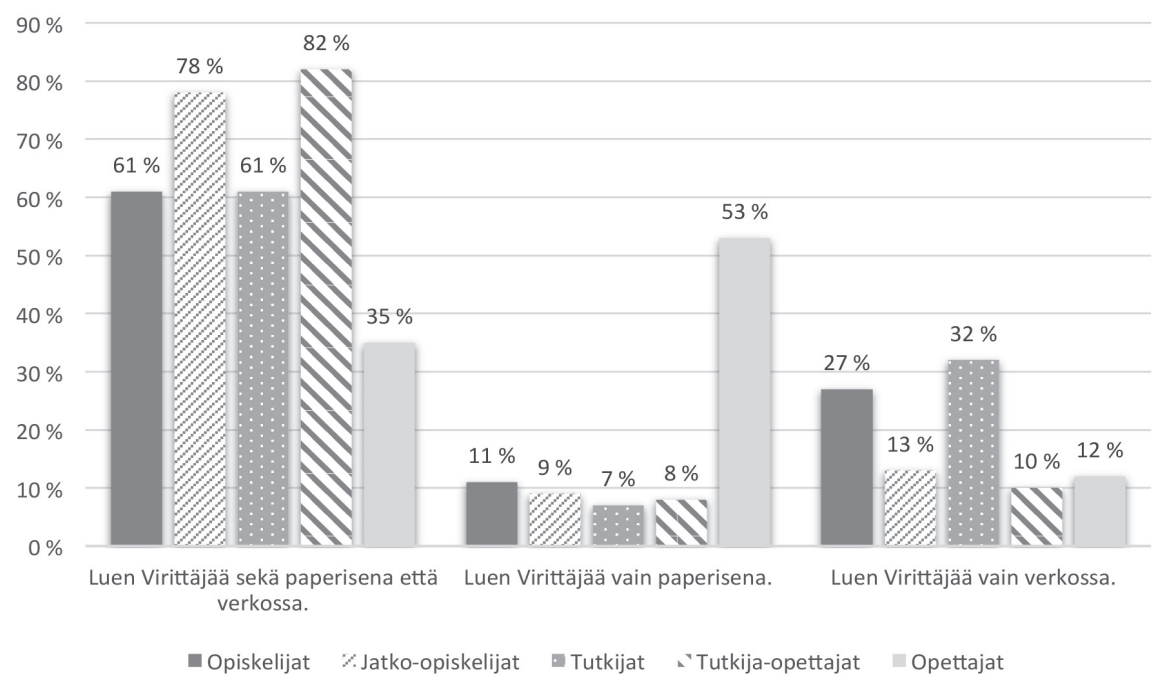

Kuvio 2.

Paperi- ja verkkolehden lukeminen vastaajaryhmittäin.

myös, käyttävätkö he näitä eri versioita samoihin tarkoituksiin. Tähän kysymykseen otti kantaa 140 vastaajaa, joista 64 prosenttia vastasi siihen myönteisesti. Kuten kuviosta 3 (seur. sivulla) käy ilmi, kirjoitusten lukemisessa paperilehteä pidetään selvästi verkkoversiota parempana, kun taas tiedonhaussa verkkolehti koetaan ylivoimaisesti paperista paremmaksi. Kirjoitusten selailussa kumpikaan versio ei nouse selvästi toista suositummaksi.

Vastaajat saivat arvioida eri versioiden sopivuutta myös itse esittämiinsä käyttötarkoituksiin. Tässä yhteydessä mainittiin esimerkiksi verkkoversion parempi soveltuvuus opetuskäyttöön (lähdekirjallisuuden neuvominen, artikkelin linkittäminen opiskelijoille). Verkkolehden katsottiin olevan parempi myös arkistoinnin kannalta sekä silloin, kun kyse on yksittäisen lähdeviitteen tarkistamisesta, artikkelitiedon lähettämisestä toiselle esimerkiksi sähköpostitse tai oikeinkirjoitusvinkkien hakemisesta. Verkkoversion sanahakutoiminto keräsi kehuja useammassa vastauksessa. Paperilehden lukemisen taas koettiin olevan nautinnollisempaa: painettu lehti sopii paremmin kotona sohvalla lueskeluun, ja sitä on myös "kiva vilkaista" vaikkapa kahvihuoneessa. Joillekin verkkoversio on vain hätävara, kun paperilehti ei ole saatavilla.

Vastaajilta kysyttiin myös, tulisiko Virittäjän jatkossakin ilmestyä painettuna lehtenä. Kaikkiaan 44 prosenttia kannattaa painetun lehden säilyttämistä, kun taas 22 prosenttia vastaajista ei koe sitä tarpeelliseksi. Lopuille 34 prosentille asialla ei ole merkitystä. Painetun lehden säilyttämisen kannalla olevista vastaajista yli kolmannes lukee lehteä ainoastaan paperisena. Paperilehden kannattajia on varsin tasaisesti kaikissa ikäryhmissä. Kun tarkastellaan vastaajaryhmiä, eniten kannatusta on opettajien, opiskelijoiden ja jatko-opiskelijoiden parissa: näissä ryhmissä noin puolet vastaajista pitää paperilehden säilyttämistä tärkeänä. Tilaajista painetun version säilyttämisen kannattajia on hieman yli puolet.

Kuuden vuoden takaisessa kyselyssä kysymyksenasettelu oli hieman erilainen, sillä Virittäjän verkkolehti oli tuolloin uusi asia. Vuoden 2011 kyselyssä vastaajia pyydettiin vertailemaan paperi- ja verkkoversiota lähinnä siinä suhteessa, miten nämä kaksi eri versiota tulisi hinnoitella. Näistä vastauksista voi kuitenkin 


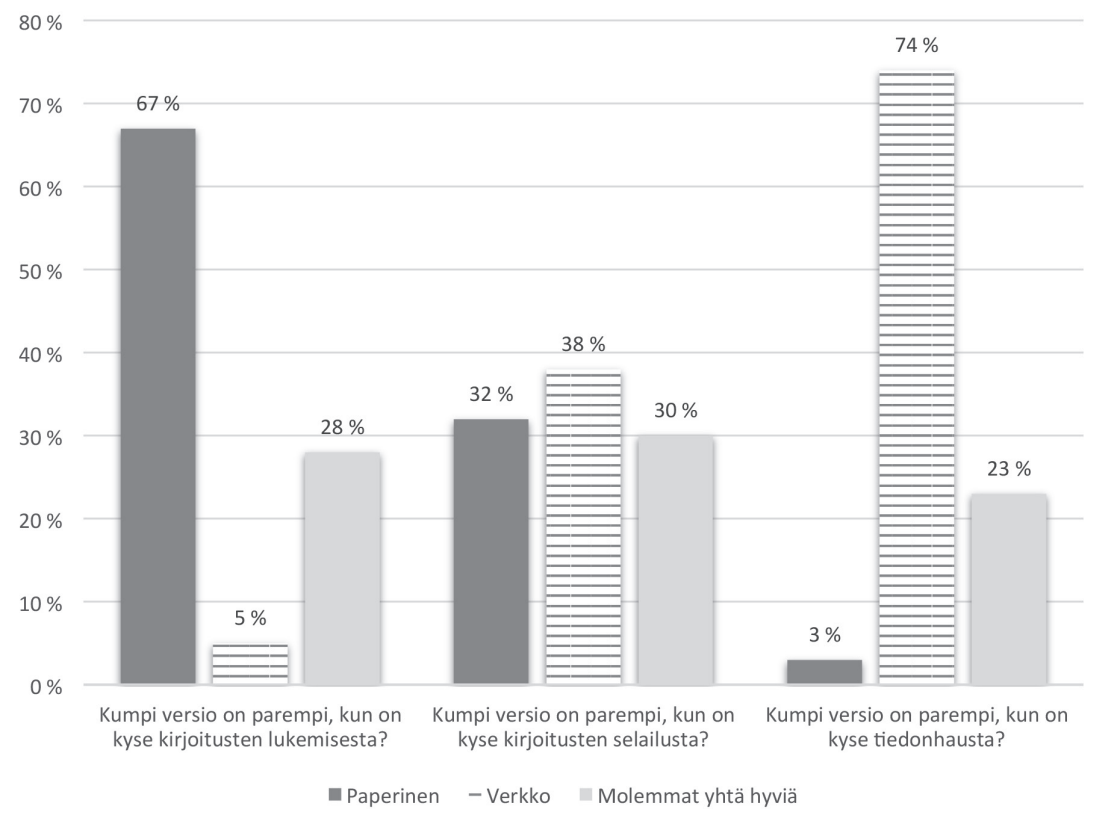

Kuvio 3.

Paperi- ja verkkolehden käyttötapojen vertailu.

päätellä, että tuolloinkin opiskelijat olivat varsin vahvasti paperilehden säilyttämisen kannalla. (Niskanen \& Mäntynen 2012: 127-128.) Siitä huolimatta, että verkkoversio nähdään nykyään jo aivan elimellisenä osana Virittäjän toimintaa eikä siitä luopumista ehdottanut kukaan, paperilehdellä tuntuu olevan edelleen vahvaa kannatusta. Tämä on tärkeä tieto. Paino- ja postikulujen noustua viime vuosina huomattavasti Virittäjä on joutunut korottamaan tilausmaksuja. Se ei näytä vielä ratkaisevasti vaikuttaneen siihen, että tilaajat olisivat vaihtaneet paperilehdestä VerkkoVirittäjään, joka on selvästi painetun lehden tilausta edullisempi. Erityisen tuntuva tämä hintaero on muille kuin opiskelijoille.

Niistä vastaajista, jotka ovat sitä mieltä, että pelkkä sähköinen versio riittää, tilaajia on 44 prosenttia. Heistä ainoastaan kaksi tilaa tällä hetkellä pelkkää verkkolehteä. Yli puolet sähköisen version kannattajista on Virittään entisiä tilaajia. Eniten pelkän verkkolehden kannattajissa on tutkija-opettajia, mutta toisaalta yhtä suuri osa tästä ryhmästä on paperilehden säilyttämisen kannalla. Tutkimukseen osallistuneista opiskelijoista ja jatko-opiskelijoista pelkkää verkkolehteä puoltaa ainoastaan noin joka kymmenes. Keskeinen peruste monelle verkkolehden suosijalle on paperisen Virittäjän viemä tila. Osa lukee sitä töissä mutta tilaa itse vain digilehteä.

Jotkut kokivat kysymykseen vastaamisen vaikeaksi:

"Se, pitäisikö paperinen lehti säilyttää ei ole minulle yksiselitteinen. Mikään vastausvaihtoehdoista ei ollut hyvä. Pidän ensisijaisesti paperisesta lehdestä, mutta jos muuttuminen pelkäksi sähköiseksi lehdeksi takaisi laajojen artikkelien määrän kasvattamisen, olisin valmis kannattamaan sähköistä versiota."

Myös muissa kommenteissa uumoillaan, että paperiversiosta luopuminen nopeuttaisi julkaisuaikoja. Tässä voidaan todeta, että artikkelien määrää ja niiden julkaisu- 
prosessin kestoa ei ensisijaisesti rajoita lehden painaminen ja sivumäärän kasvusta aiheutuvat painokulut vaan ennemminkin rajalliset toimitusresurssit. Artikkelien taakse kätkeytyy pitkä ja monivaiheinen toimitusprosessi, joka vaatii työtä.

Monella ei ole eri versioiden paremmuudesta siis täysin selvää kantaa, vaan siihen vaikuttavat useat seikat. Toisilla sen sijaan on vankka näkemys:

"Paperilehti lienee tarpeellinen vain niille, jotka ovat saaneet oman artikkelinsa Virittäjään ja haluavat hypistellä tuotostaan fyysisenä objektina. Muille riittää verkkolehti (verkkolehti toimii hyvin artikkelien lukemiseen, kokonaisiin kirjoihin ei). Jos ja kun rahat ovat tiukassa, antiikkisesta paperilehdestä pitäisi ehdottomasti luopua. Ja voitaisiinhan Virittäjästä julkaista pdf, josta kukin voisi niin halutessaan printata haluamansa lehden."

Yksi vastaajista ehdottaa paperilehden ja verkkoversion eriyttämistä toisistaan:

"Mielestäni paperiversiossa voisi kes-
kittyä tutkimusartikkeleihin ja julkaista
muita osastoja vain verkossa (kuten jo
nyt lektiot) Esimerkiksi kirjallisuus-
arvioihin ja erilaisiin katsauksiin on
harvoin tarve palata toisin kuin artik-
keleihin, joita on kätevämpi käyttää
lähteenä paperisena kuin sähköisenä.
Jos muita kirjoituksia julkaistaisiin pai-
nettuna vähemmän, artikkeleille tulisi
lisää tilaa. Toisaalta kaikki mikä on vain
verkossa, jää paljon helpommin luke-
matta kuin paperilehdessä julkaistut."

Eräs vastaaja toteaa sähköisen version riittävän, mutta sen ilmestymisestä olisi ehdottomasti saatava tieto sähköpostiin, jotta sen muistaisi käydä lukemassa. Kyseinen vastaaja ei kaikesta päätellen ole rekisteröitynyt OJS-järjestelmään, sillä sitä kautta kaikki Virittäjän lukijat ja kir- joittajat saavat nykyään automaattisesti ilmoituksen heti, kun uusi numero on julkaistu verkossa.

\section{Virittäjän hinnoittelu}

Vastaajilta tiedusteltiin myös sitä, paljonko he olisivat valmiita maksamaan painetusta Virittäjästä. Opiskelijatilaushintaan otti kantaa 68 prosenttia ja normaalitilaushintaan 87 prosenttia vastaajista. Molemmissa tilaustyypeissä vastaukset painottuvat tarjolla olleista vaihtoehdoista edullisimpiin. Painetun lehden opiskelijatilauksesta noin puolet vastanneista olisi valmis maksamaan alle 30 euroa vuodessa. Virittäjän opiskelijahinta (28 euroa) on korotuspaineista huolimatta haluttu pitää matalana, ja se ei herättänytkään juuri kritiikkiä. Normaalitilaushintaan kantaa ottaneista suurin osa, noin 60 prosenttia, ilmoittaa sen sijaan olevansa valmis maksamaan Virittäjästä vähemmän kuin nykyisen hinnan eli alle 70 euroa vuodessa. Heistä tämänhetkisiä tilaajia on noin kolmannes. Nykyhintaan (77 euroa) tyytyväisiä vastaajista oli samoin kolmasosa, sillä he olivat valinneet sopivaksi hinnaksi 7080 euroa vuodessa. Tätä enemmän ilmoittaa olevansa valmis maksamaan vain 10 prosenttia kysymykseen vastanneista.

Vastausten perusteluista käy ilmi, että korkeammat tilaushinnat eivät innosta, koska artikkelit löytyvät kirjastosta tai verkosta tai koska lehteä voi lukea työpaikalla. Myös tilan puute vaikuttaa siihen, ettei paperisesta lehdestä haluta maksaa. Pari vastaajaa ei halua tilata paperilehteä ekologisista syistä, mutta myös painetulla lehdellä on kannattajansa, jotka ovat valmiita maksamaan siitä:

"Painetun lehden hinta saa minusta olla kalliimpi kuin pelkän verkkolehden. Ehkä olen vanhanaikainen, mutta voi tulla aika, jolloin verkko ei enää toimi niin kuin pitäisi. Jos kaikki on vaan verkossa, mitä sitten tehdään? 
Ainakin yliopiston kirjastoille pitäisi olla myös painetut lehdet.”

\section{Avoimen julkaisemisen vaikutus tilaamiseen}

Nykyään Virittäjä on verkossa heti tilaajien luettavissa, kun taas muille sisällöt avautuvat vasta 12 kuukauden embargoajan jälkeen. Vastaajilta tiedusteltiin, tilaisivatko he Virittäjän, jos se julkaistaisiin heti ilmestyttyään avoimesti verkossa. Kysymys ei ollut mukana vain muodon vuoksi, vaan kun paineet nykyistäkin avoimempaan julkaisupolitiikkaan kasvavat, myös Virittäjä on joutunut pohtimaan omaa linjaansa. Pysyäkseen mukana tiedejulkaisemisen muutoksissa lehti on osallistunut Kotilava-hankkeeseen, jossa on pyritty rakentamaan uudenlaista tiedejulkaisemisen rahoitusmallia (ks. www. kotilava.fi). Tavoitteena on ollut löytää kestävä ratkaisu, jolla tieteellisten lehtien toiminta turvattaisiin, kun avoin julkaiseminen väistämättä karsii tilaajia ja kurjistaa lehtien ennestäänkin tiukkaa taloutta vaatiihan pelkkä verkkojulkaiseminenkin huomattavan määrän työtä ja taloudellisia resursseja. Toiveena on ollut saada yliopistojen ja ammattikorkeakoulujen kirjastoista lehtien rahoittajia, sillä juuri ne hyötyisivät avoimesta julkaisemisesta. Vastineeksi kokeilussa mukana olevat lehdet ovat sitoutuneet välittömään avoimeen julkaisemiseen. Toistaiseksi neuvottelut ovat kuitenkin kesken ja Virittäjä jatkaa nykyisellä linjallaan.

Vaikka Virittäjä julkaistaisiin avoimesti verkossa ilman embargoaikaa, 17 prosenttia vastaajista ilmoitti jatkavansa tilaajina saadakseen itselleen painetun lehden ja 26 prosenttia tukeakseen Virittäjää. 23 vastaajaa oli valinnut molemmat vaihtoehdot. Sen sijaan noin kolmannes ilmoitti, ettei tilaisi Virittäjää tällaisessa tapauksessa. Tästä joukosta kolmasosa on nykyisiä tilaajia. Huomattava osa vastaajista, noin kolmannes, ei osannut ottaa asiaan tässä vaiheessa kantaa. Kyselyn valossa vaikuttaa siis siltä, että tilaajamäärä jossain määrin vähenisi, jos Virittäjä olisi luettavissa verkossa heti kaikille vapaasti. Tätä kommentoivat myös vastaajat, esimerkiksi näin:

"Kukapa maksaisi aineistosta, joka on ilmaiseksikin saatavilla - korkeintaan ne, jotka voivat kiikuttaa laskun työnantajalleen."

Lehden lukijoissa ja tilaajissa on myös runsaasti niitä, jotka ovat valmiita jatkamaan lehden tilaajina ensisijaisesti sitä tukeakseen. Useimmat kuitenkin perustelivat tilauksen jatkamista sillä, että lukevat mieluummin paperilehteä: " $[\mathrm{P}]$ aperinen lehti voittaa sähköisen lehden 6-o." Painettua lehteä puoltaa myös jo edellä esiin tullut lukumukavuus, mutta muitakin syitä mainittiin: Paperilehteä tulee esimerkiksi luettua säännöllisemmin. Osa myös kokee, että painetun lehden lukemiseen on helpompi keskittyä kuin verkkolehden.

Vastaajilta kysyttiin lisäksi, olisivatko he valmiita nykyistä suurempaan Kotikielen Seuran jäsenmaksuun, jos Virittäjä ilmestyisi ainoastaan avoimena verkkolehtenä ja tilausmaksu poistuisi kokonaan. Tällä hetkellä suurin osa tilaajista on Kotikielen Seuran jäseniä, ja seuran pieni jäsenmaksu (3/6 euroa) sisältyy tilaushintaan. Seuran johtokunta on pohtinut sitä mahdollisuutta, että tätä nimellistä jäsenmaksua korottamalla voitaisiin turvata Virittäjän toimintaedellytykset. Yli puolet vastasi kysymykseen myöntävästi; näistä vastaajista nykyisiä tilaajia on hieman yli puolet. Sen sijaan runsas kolmannes oli kielteisellä kannalla, ja tästä joukosta lehden tilaajia oli kolmannes. Muutama perusteli kielteistä vastaustaan sillä, ettei ole seuran jäsen tälläkään hetkellä.

Vastaajista 59 prosenttia kertoi olevansa kiinnostuneita verkossa julkaistavasta Virittäjän näköispainoksesta eli koko lehden kattavasta pdf-tiedostosta. Tästä joukosta tilaajia on 41 prosenttia. Huomionarvoinen 
seikka on, että tutkimukseen osallistuneista opiskelijoista 70 prosenttia oli kiinnostuneita tästä mahdollisuudesta ja jatkoopiskelijoistakin lähes yhtä suuri osa; muissa ryhmissä kiinnostus oli hivenen vähäisempää. Noin kolmannes vastaajista sen sijaan ei pitänyt pdf-muotoista näköispainosta tarpeellisena. Sitä kommentoitiin kömpelöksi ja vanhanaikaiseksi, eikä sen koettu tuovan mitään lisäarvoa.

\section{Virittäjän sisältö ja ulkoasu}

Viimeisessä osiossa keskityttiin Virittäjän sisältöön ja ulkoasuun liittyviin seikkoihin. Vastaajilta tiedusteltiin muun muassa, mitä osioita he lehdestä lukevat. Suosituimmaksi kirjoitustyypiksi osoittautuivat odotuksenmukaisesti artikkelit, joita ilmoitti lukevansa 88 prosenttia. Toiseksi eniten luetaan Havaintoja ja keskustelua -osastoa (68\%), ja miltei saman verran lukijoita on kirjallisuusosastolla (59 \%) ja katsauksilla (59 \%). Pelkästään verkkolehdessä ilmestyviä lektioitakin ilmoitti lukevansa lähes puolet (48 \%). Kaikkiaan eri juttutyypeillä on ilahduttavan paljon lukijoita, mistä kertoo sekin, että vastaajista kolmannes ilmoitti lukevansa kaikkia lehden osastoja.

Vastaajat saivat myös esittää Virittäjän sisältöä koskevia toiveita ja kertoa, millaisia juttuja tahtoisivat jatkossa lukea. Ehdotuksia tuli runsaasti, kaikkiaan sata. Moni piti nykytarjontaa hyvänä ja kiinnostavana, ja monipuolista kielitieteellistä sisältöä kannatettiin laajasti: "En lähtisi rajaamaan; älkää tekään!" Ehdotettujen aihepiirien kirjo on laaja ja heijastelee epäilemättä vastaajien omia kiinnostuksen kohteita. Vaikka omaa erikoisalaa käsittelevät artikkelit koetaan luonnollisesti mielenkiintoisimmiksi, moni kertoi lukevansa mielellään muistakin aiheista. Osa toiveista paljasti, että kaikki vastaajat eivät tunne kovin hyvin Virittäjän nykyistä sisältöä. Esimerkiksi tuoreita väitöskirjoja esitellään lähes joka numerossa, ja kahtena peräkkäisenä vuotena järjestettyjen kirjoituskilpailujen ideana on ollut nostaa ansiokkaita kandidaatintutkielmia ja pro graduja tiedeyhteisön tietoisuuteen (ks. Tjukanov 2016; Vierula 2017; Satokangas 2018). Edelleenkin opinnäytetöihin pohjaavat havaintokirjoitukset ovat tervetulleita, samoin kuin muutkin lyhyet kirjoitukset ja keskustelupuheenvuorot. Tällä hetkellä tarjonta painottuu turhan yksipuolisesti artikkeleihin.

Vastaajat pääsivät myös esittämään näkemyksiään Virittäjän ulkoasusta. Siihen ollaan pääsääntöisesti tyytyväisiä, ja esimerkiksi vaihtuvien vuosivärien kerrottiin helpottavan oikean numeron löytämistä. Ulkoasua luonnehdittiin muun muassa tyylikkääksi, harmoniseksi, raikkaaksi ja selkeäksi. Yhtenäisyys koetaan perinteisessä julkaisussa tärkeäksi. Makua on luonnollisesti monenlaista, ja esimerkiksi kansien pastellivärit eivät miellytä kaikkia, vaan muutamat kaipasivat ulkoasuun lisää väriä. Värejä toivottiin myös kirjoituksissa esitettyihin kuvioihin. Yksittäisissä vastauksissa peräänkuulutettiin esimerkiksi suurempaa fonttia ja ehdotettiin sisällysluettelon palauttamista lehden takakanteen.

Virittäjä on juuri perustamassa omaa blogia, jossa esimerkiksi artikkeleiden kirjoittajat voivat kertoa keskeisistä tuloksistaan yleistajuisesti. Kyselyssä tiedusteltiin kiinnostusta tällaisen blogin lukemiseen. Oli ilahduttavaa huomata, että blogi herättää mielenkiintoa ja sille on selvää tilausta. Yli 80 prosenttia vastaajista nimittäin ilmaisi olevansa kiinnostuneita blogista. Kyselyssä kartoitettiin myös blogiteksteihin kohdistuvia toiveita. Vastauksissa korostuivat lyhyys, ytimekkyys, ajankohtaisuus ja yleistajuisuus.

Blogikirjoitukset nähdään toimivana kanavana levittää tutkimustietoa suurelle yleisölle:

"Niiden avulla voisi jakaa kielitieteellistä tietoa myös muille kuin lingvistisesti koulutetuille kontakteille." 
Blogitekstin laatimista ehdotettiin jopa artikkelin kirjoittamiseen liittyväksi velvollisuudeksi:

"Mielestäni tällaisen blogitekstin kirjoittaminen pitäisi olla kullekin artikkelin Virittäjässä julkaisseelle pakollista, jotta tulokset leviäisivät ja jotta tutkijat tulisivat todella miettineeksi, mikä tutkimuksessani on yleisesti relevanttia ja miten esittelen asiani kiinnostavasti ja selkeästi suurelle yleisölle."

Vastauksista erottuu karkeasti kaksi päälinjaa: opetus ja tutkimus. Joissakin vastauksissa ne kietoutuvat yhteen, sillä tutkimukseen perustuva yleistajuinen blogikirjoitus voisi olla hyödyksi esimerkiksi suomen kielen yliopisto-opetuksessa ja helpottaa varsinaisen artikkelin lukemista. Opetukseen liittyviltä blogiteksteiltä kaivataan havainnollisuutta. Blogin toivotaan antavan tukea myös tutkimuksen tekoon. Moni ehdottaa, että blogikirjoituksissa voisi avata tutkimuksen tekemistä tai artikkelin kirjoittamista esimerkiksi kertomalla artikkelin työstämisestä ja syntymisestä tai esittelemällä tutkimusta taustoittavia prosesseja yleistajuisesti. Blogikirjoituksessa voisi myös kertoa, mitä varsinaisesta artikkelista piti jättää pois. Eräs vastaaja kuitenkin aiheellisesti muistuttaa, että blogitekstin tulee toimia myös ilman siihen liittyvää artikkelia, vaikka artikkeli sitä syventäisikin.

Blogiteksteiltä toivotaan myös tietoa siitä, kuinka tutkimusta voi soveltaa käytäntöön tai miten se kytkeytyy yhteiskunnallisiin kysymyksiin. Kirjoituksiin kaivataan kantaaottavuutta ja kyseenalaistavuutta niin yhteiskunnallisesti kuin tutkimusperinteenkin kannalta. Kannanottoja toivotaan esimerkiksi kielipolitiikkaan, nykymarkkinointiin ja ylipäätään median esiin nostamiin suomen kieleen linkittyvin ilmiöihin. Tyylilaji voisi olla artikkelia vapaampi:
"Blogissa saisi vähän irrotella ja tehdä ajatuskokeita ja provokaatioita."

\section{Lopuksi}

Kaikkiaan kysely osoitti, että Virittäällä on edelleen vahva sitoutunut lukija- ja tilaajakuntansa. Lukijat ovat lehden sisältöön ja ulkonäköön varsin tyytyväisiä, eikä kyselyssä noussut esiin mitään merkittäviä, laajaa joukkoa yhdistäviä muutostoiveita. Suurin osa hyödyntää sekä paperi- että verkkolehteä ja näkee molemmilla oman paikkansa. Osa vastaajista olisi valmis siirtymään pelkkään verkkolehteen ja tukemaan sen toimintaa myös taloudellisesti tavalla tai toisella, mutta painetulla lehdellä on edelleen niin selvä kannatus, ettei tämän kyselyn valossa ole syytä vielä päätellä, että paperiversion aika olisi ohi. Huomiota kiinnittää se, että painettua lehteä kannattavat hyvin vahvasti myös opiskelijat, jotka edustavat tulevaisuutta ja vastaajien nuorinta ikäpolvea. Painetun lehden ongelmaksi voi kuitenkin muodostua tilaajamäärän väheneminen, mikä näyttää väistämättömältä, jos lehti on heti ilmestyttyään vapaasti luettavissa verkossa. Paperilehden tilaajamäärän väheneminen nimittäin johtaisi painokustannusten suhteelliseen kallistumiseen. Kyselyn valossa harva on halukas maksamaan nykyistä suurempaa tilausmaksua. Toimituksen näkökulmasta olisikin toivottavaa, että lehden arvostaminen näkyisi myös käytännössä - esimerkiksi verkkotilauksina. Tämä vaihtoehto tuntuu unohtuneen niiltä, jotka eivät halua kerätä kotiinsa paperista arkistoa mutta joilla on silti halua tukea kotimaista tieteellistä julkaisemista.

Jenni Neuvonen

HANNA LAPPALAINEN etunimi.sukunimi@helsinki.fi

Jenni Neuvonen on suomen kielen jatko-opiskelija Helsingin yliopistossa ja Hanna Lappalainen Virittäjän päätoimittaja. 


\author{
Lähteet \\ Niskanen, Ninna - Mäntynen, Anne \\ 2012: Virittäjän lukijakyselyn tuloksia. \\ - Virittäjä 116 s. 125-131. \\ SATOKANGAS, Henri 2018: Uskonnon \\ oppikirjojen moniäänistymiskehitys ja \\ muuttuva ryhmäkonstruointi. - Virittäjä \\ 122 s. $112-121$.
}

TuUkanov, Maija 2016: Kielet kerroksittain - suomen kielen ja suomalaisen viittomakielen simultaania yhteistyötä keskustelussa. - Virittäjä 120 s. 583-594.

Vierula, Suvi 2017: Kanssa, kans ja kaa - postposition muutoksen tarkastelua. - Virittäjä 121 s. 265-275. https://doi. org/10.23982/vir.61037.

\section{Kielenvälityksestä arkikeskusteluissa}

\author{
Katariina Harjunpää: Translatory prac- \\ tices in everyday conversation. Bilingual \\ mediating in Finnish-Brazilian Portuguese \\ interaction. Helsinki: Helsingin yliopisto \\ 2017. 308 s. ISBN 978-951-51-3226-0.
}

Katariina Harjunpää tutkii monografiaväitöskirjassaan sitä, miten maallikkokääntäminen jäsentyy vuorovaikutuksellisesti monikielisissä arkikeskusteluissa. Tutkimusaineisto muodostuu erilaisissa ateriointi- ja muissa seurustelutilanteissa tuttavien ja perheenjäsenten kesken käydyistä keskusteluista. Osanottajien kielelliset repertoaarit ovat epäsymmetriset: osa on yksikielisiä ja osa enemmän tai vähemmän kaksikielisiä. Pääaineisto, laajuudeltaan noin yhdeksän tuntia, käsittää neljä videotallennetta, joista kolme on kuvattu Brasialiassa ja yksi Suomessa. Keskustelun kielinä ovat suomi ja brasilianportugali, toisinaan myös englanti lingua francana. Metodologisesti tutkimus edustaa multimodaalista keskustelunanalyysia. Työn keskiössä ovat vuorot, joissa vaihdetaan keskustelun kieltä ja jotka ovat tulkittavissa aiemman puheen välitykseksi toisille keskustelun osanottajille. Teok- sessa on johdannon ja tutkimusongelmaa taustoittavan luvun lisäksi neljä analyysilukua sekä pohdinta- ja johtopäätösosuus.

\section{Tutkimusongelmat}

Kääntämistä ja tulkkausta, jotka kuuluvat ilmiöinä monikieliseen vuorovaikutukseen, esiintyy niin arki- kuin institutionaalisissa keskusteluissa. Harjunpää lähtee tutkimusongelmansa muotoilussa liikkeelle tästä keskustelunanalyyttisesta erottelusta kahden keskustelutyypin välillä. Empiirisenä, aineistosta nousevana lähtökohtana on, että arkikeskusteluissa kääntäminen (tai tulkkaus) ei ole systemaattista vaan sitä esiintyy vain paikoitellen. Ammatillisesta kääntämisestä poiketen maallikkokääntäjällä ei ole ennalta määrättyä kääntäjän roolia, vaan hän on keskustelussa mukana yhdenvertaisena osanottajana muiden joukossa. Kielenvälityksen ${ }^{1}$ tarve syntyy monikielisissä

1. Ammattikääntämisen ja -tulkkauksen ulkopuolisia kääntämisen ja tulkkauksen ilmiöitä koskevasta terminologiasta ks. myös Pilke, Kolehmainen \& Penttilä 2015. 